\title{
Rethinking World Literature Studies in Latin American and Spanish Contexts
}

\author{
Marta Puxan-Oliva \\ Universitat de Barcelona \\ marta.puxan@ub.edu \\ Annalisa Mirizio \\ Universitat de Barcelona \\ annalisamirizio@ub.edu
}

\section{Rethinking World Literature Studies}

This issue presents a collection of essays which address, from the perspectives of distinct critical traditions, the epistemological framework and central problems of World Literature Studies-both its most original contributions (de-Eurocentering Weltliteratur, addressing various levels of culture, centering the circulation of texts and their translation, the role of the market), as well as its dialogue with classic comparative approaches. The term "rethinking" used in the title of the issue is not meant in the sense of adding fuel to the debatelively enough as it is - around the very notion of World Literature (Damrosch, Moretti, Casanova, and David, among others), but denotes an operation that is essential to any critical endeavor: the interrogation of theories and methods that underlie the reading of a text (as Raymond Williams and Edward Said have argued). We assume World Literature as a mode of comparativism that integrates the classical concerns of Comparative Literature about supranational relationships between texts, with the "secular" criticism of Cultural Studies and its attention to context.

In order to make our position clear, it should be noted that this issue for the most part does not question the concept of World Literature as a field of study, and leaves out the discussion of its pedagogical value in the teaching of literature, as well as the related debates on the controversial redrawing of literary canons encompassed by this critical approach. The essays gathered here do not address World Literature as a method that might draw upon a gathering of big data for organizing the undifferentiated magma of all literary 
texts, produced at all times and in all places (Moretti "Conjectures"; "More Conjectures"; Graphs, Maps, Trees). They mostly take literary texts in their contextual relations, or "ecologies," but they do not consider language as the central axis to which reflection is mostly moored (Beecroft "World Literature"; An Ecology).

Our approach consists in adopting World Literature as a mode of thinking the literary text in its circulation in different geographical and critical contexts. We take World Literature as originally formulated by David Damrosch: "My claim is that world literature is not an infinite, ungraspable canon of works but rather a mode of circulation and of reading" (Damrosch What 5), rather than the concept as it appears in his later work "World Literature as an Alternative Discourse." Our notion is also in line with Gisèle Sapiro's "How do Literary Works Cross Borders (or Not)?"; however, we do not necessarily understand circulation and reading as exclusively dependent on translation either, something that Emily Apter has objected to in Against World Literature.

We concentrate specifically on the problems in the circulation of literature in critical contexts and critical traditions, and in particular on how circulation produces different histories of comparativism, or comparativisms, related to national critical traditions - on the frictions between literary and geopolitical maps, between notions of literary citizenship and foreignness, between real and imagined places, and between political strategies and diplomatic actions.

\section{Latin American and Spanish Critical Contexts}

These issues are predominantly considered from the Latin American and Spanish perspectives, as the title suggests, although a clarification would not be amiss. We work from the Latin American and Spanish contexts, but our primary goal is not to add a few more regional or national bricks to a global wall. Rather, our wish is to make visible some critical traditions rooted in Latin American countries and to underline their suitability for World Literature Studies. Indeed, this collection of texts is, among other things, evidence of the active participation of Latin American and Spanish scholars in the definition, translation, and diffusion of comparativism, as well as in the expansion and the reformulation of this field of study. Nevertheless, the contributions of Latin American critical traditions have been frequently understood as derivative of European or North American debates, and peripheral to these. Or, as Fernando Cabo Aseguinolaza notes, this comparativism has been inscribed in the history of the discipline as a "world regionalism [that] goes hand in hand with the impossibility of accessing visibility and mainstream flow of circulation.” 
We believe that, by drawing from Latin American and Spanish contexts, this issue proposes theories for literature and theories of comparativism that might enrich current modes of thinking the literary text in World Literature Studies; for the theories proposed here do not dispense with the problems of literature, nor the effects inscribed by geography in literary institutions, markets, critics, and the reading public.

The territories referred to in the texts gathered here are spaces inhabited by individuals, languages, and books - territories that (whether real or symbolic) intervene as a constructive element in literary creation as well as in its critical reception, in the politics of translation and its circuits. In this sense, the texts also address the conditions under which World Literature Studies is integrated into the theoretical discourses within the Spanish academy, and in particular the extent to which a reformulated comparativism has been assimilated into the traditional one.

As César Domínguez has argued in his article "Literatura mundial en/desde el castellano" (World Literature in/from Spanish), two factors partially explain the hitherto scant interest for World Literature in (peninsular) Spanish literary studies: "on the one hand, the rejection of a traditionalist and reactionary legacy of a 'Universal Literature,' which not even the substitution of a politically correct 'World Literature' seemed to mitigate in the eyes of a Comparative Literature ... and, on the other hand, the state of the discipline of Comparative Literature" in Spain (Domínguez 4, our translation). The fairly recent emergence of Comparative Literature as a distinct critical approach, and the genuinely comparative perspective within the traditionally strong area of philological studies in twentieth-century Spain, might explain the rather tentative and somewhat indifferent response to World Literature as a critical approach. ${ }^{1}$ Even Hispanism, which Fernando Cabo Aseguinolaza examines in his contribution to this issue, has recently expanded as a set of post-national and transatlantic literary perspectives that perceive themselves as comparative, although not necessarily as engaged with the classic parameters of Comparative Literature-since the basis of the field is a common language and a shared colonial history — or with a World Literature perspective, and yet an "implicit comparativism" is also practiced in this field. ${ }^{2}$

1 See the entire issue of Ínsula (no. 788-9), "Literatura mundial: una mirada panhispánica," dedicated to World Literature from a panhispanic perspective and in dialogue with Comparative Literature.

2 Until very recently, Spanish Peninsular literatures elicited independent critical traditions, which are now beginning to develop a promising comparative perspective under the label 
The critical traditions of literary studies in Latin American countries present a very different case. It is particularly relevant here to acknowledge the crucial impact of certain literary approaches to criticism in Latin American countries, above all in Argentina. The impact and legacy of sociological and Marxist approaches, psychoanalysis, and Literary Theory on literary studies in Argentina from the mid-1950s to the 1970 - - mostly received from or filtered through France, and in translation - was so great that it led Susana Cella to refer to this period as the "irruption of criticism" ("la irrupción de la crítica") (Cella; Gerbaudo; Hidalgo Nácher). This criticism has left a profound imprint on comparative studies of literature in Argentina which remains evident todayand is currently being mapped by Analía Gerbaudo and her research team involved in Gisèle Sapiro's European project INT ERCO SSH, to which Gerbaudo refers in her essay.

While strongly influenced by Literary Theory and Critical Theory, comparative studies of literature in Latin American and Spanish contexts have been marked by, and developed in parallel with, the institutionalization of Comparative Literature as a field of study, especially since the 1990s-with Brazil and Argentina as the first centers (Coutinho; Pulido Tirado "Del comparatismo espontáneo"). The revival of translation studies and of the study of the circulation of literature, on the one hand, and the rise of approaches that have focused on relations of geography, power and politics in literary criticism-mostly cultural studies, gender studies, postcolonial studies, studies on globalization, all of which converge in their opposition to Eurocentrism and North-American dominance in literary criticism - on the other, were not new to Latin American critical traditions. This was due to the circulation in this broad intellectual space of the sociology of literature, intellectual history, debates on the multifaceted relations between politics and literature, and a sensitivity to the wider, international impact in the formation of Latin American literatures and criticism. ${ }^{3}$ The focal interests of World Literature in these two aforementioned

of "Iberian Studies." A similar movement may be observed within Portuguese comprativism, where criticism is becoming "Hispano-americanized," while Latin American criticism in turn is striving to absorb Portuguese influences (López et al. 9).

3 Discussions of the relations between society and literature from the perspectives of sociological studies of literature can be found in Beatriz Sarlo and Carlos Altamirano's Literatura/Sociedad; debates on politics and literature are traced in Claudia Gilman's Entre la Pluma y el Fusil and in Maria Teresa Gramuglio's Nacionalismo y Cosmopolitismo, and show the widespread influence of these critical traditions. Likewise, the volumes of Historia de los Intelectuales en América Latina, edited by Altamirano, account for the importance of intellectual history in literary criticism to the present day. 
directions in fact partially address certain concerns that are already at the heart of the most relevant critical traditions in Latin American countries. ${ }^{4}$

The question that arises, therefore, is: How can comparative literary criticism produced in Latin American countries enter into dialogue with, and contribute to, nuancing or reevaluating some of the tenets of World Literature as a critical approach? We share Ignacio Sánchez-Prado's concern, expressed in his introduction to América Latina en la "literatura mundial," that "in many cases Latin America still is the place to produce 'cases of study,' but not a legitimate locus of theoretical enunciation" (9). For the reasons just exposed, we agree with Héctor Hoyos when he proposes that "Latin Americanism, which has indeed a rich political tradition to draw from, could invigorate world literature debates, especially because it does not sacrifice close reading or attention to the specific forms of works of art in the name of politics" (10). This special issue does not make the same contention, but it certainly draws on the strong critical traditions referred to by Hoyos, in order to make specific contributions to, above all, the political, spatial, and methodological aspects of the worldly circulation of literature and criticism. We believe, therefore, that the most relevant contribution to World Literature can be made by initiating a dialogue between different critical traditions, precisely by bringing in new critical perspectives that are not necessarily those from which World Literature Studies has mostly emerged, but which are concerned with some of the same problems.

In this sense, the present issue analyzes how we think literature from Latin American and Spanish contexts, rather than how we think Latin American and Spanish literatures from within their own contexts. The former is the critical space of World Literature; the latter, the critical space of Latin American and Peninsular Spanish Studies.

\section{Contributing to World Literature Debates}

As it has been argued, if World Literature is concerned with the modes of circulation of literary texts, it is also concerned with the circulation of critical and theoretical texts. In this regard, Nora Catelli revises the idea of an exclusive chronology of the evolution of Comparative Literature. As her essay shows,

4 A good example of this kind of work (Müller and Gras Miravet) examines the internationalization of Latin American literatures with a focus on editorial markets from a World Literature perspective. 
analysis of the circulation of literary theoretical discourses reveals the multiple and parallel chronologies of comparativism, and its many worlds. The aim, as suggested above, is not to offer a reformulation of comparativism, considered from a Hispanic and Latin American perspective and in light of recent debates, but rather, as Catelli explains, it is a matter of visualizing a strong comparative tradition that had emerged from "other latitudes" at a time when scholarly debates in Europe and the United States were dominated by the crisis of Comparative Literature.

Fernando Cabo Aseguinolaza also disputes the validity of a single comparativist tradition and the universal applicability of its reformulations. According to Cabo Aseguinolaza, World Literature Studies should resist the impulse to be all-embracing, which legitimizes differences while at the same time obliterating them. It should resist the temptation to obscure that which opposes it, and to reduce it to an ethnic flavor of a reinvented "world regionalism," constructed and connoted from the outside. On the contrary, based on the notions of chorology and locality, the author sets out to reconsider relations between the local and the global, bypassing the glocal, and moving beyond opposition between the two to intervene in debates on world literature.

A further elucidation of ideas emerging from World Literature Studies is articulated in Mariano Siskind's essay, whose point of departure is that the "world" that is spoken of in World Literature Studies is a world that might not exist. Thus, in line with the rest of this issue, and developing an argument outlined in Siskind's Cosmopolitan Desires: Global Modernity and World Literature in Latin America, this "world" might only be a "critical and aesthetic discourse," a longing, or a projection that, far from collapsing projection into reality, must allow the comparativist to observe the very dislocation of these projected worlds, which are undoubtedly also critical worlds.

Using the provocative metaphor of the "corpse," Héctor Hoyos revises the institutionalization of World Literature Studies so as to reflect on its aims as well as on the critic's task. According to Hoyos, the ways in which World Literature Studies are being configured, its ability to absorb opposing views, and its own dynamism might show that there is no defined target capable of ensuring or envisioning a clear future for it (it would not envision its own "death"). Building his argument upon Bolaño's corpse narratives, Hoyos proposes-in place of high-minded idealism - a "materialist" approach to face the future of the paradigm.

The essay that follows insists on the impossibility and the risks of adhering to the fantasy of a single comparativist tradition, as well as the dream of a world literature that paradoxically, as Gonzalo Aguilar points out, lacks a notion of foreignness. How does World Literature Studies approach literary texts that "are 
displaced from their national context but are also strange to other literatures"? How shall we categorize texts that are "strangers to world literature"? Taking the work of Clarice Lispector as a starting point-although it has by now entered the literary canon (as noted by Damrosch in "World Literature")Aguilar invites World Literature Studies to devise new cartographies, based on the paths traced by these writings, that are "foreign" for all.

In her article, Analía Gerbaudo also insists on the need for World Literature Studies to introduce new categories determined by the specificity of context. As a participant in the European project INTERCO SSH directed by Gisèle Sapiro, and based on one remarkably striking case, Gerbaudo has developed the new methodological categories of "stories" and "fantasies of nano-intervention." She uses them to analyze the narratives surrounding the institutionalization of literary studies in a context like Argentina, where political instability, and the need to evade censorship and persecution, gave rise to marginalized and clandestine intellectual activities that have not left any archival traces. Gerbaudo's essay demonstrates that the historico-cultural specificity of a place demands the creation of new concepts and categories that are sensitive to the distinct contexts of literary production and circulation.

With regard to the problematic circulation of literature, not only censorship, but also "diplomacy," emerges as a category that comprehends circulation in political and cultural terms, rather than in terms of literary markets. Graciela Montaldo's essay relates diplomacy to the emergence of mass cultural consumption and uses the figure of the "distinguished visitor," usually a European intellectual travelling to Latin America, to explore the industry of "live literature," an aspect hitherto often dismissed in comparativist discourses.

Finally, the essay by Álvaro Fernández Bravo studies the function of space, understood as a productive force within an aesthetic project. Starting with the real or spectral presence of Chinese poetry in the writing of Juan L. Ortiz, Fernández Bravo rethinks the idea of "province" as a locally constructed space, proposing instead a space created through borrowing from literary texts in circulation, emanating from diverse geographical contexts, in what he refers to as "provincial cosmopolitanism."

In conclusion, by attending to the circulation of literary texts, critical perspectives and theoretical discourses of comparativism, this issue calls for the rethinking of several fundamental concepts of World Literature Studies, as well as its relation to Literary Theory. By bringing Latin American and Spanish comparative criticism in dialogue with World Literature, this issue proposes that we consider contexts in World Literature Studies as places from where we think critically, rather than places that participate in World Literature from an autoethnographic standpoint. 


\section{Works Cited}

Altamirano, Carlos, ed. Historia de los intelectuales en América Latina. Buenos Aires: Katz, 2008.

Altamirano, Carlos, and Beatriz Sarlo. Literatura/sociedad. Buenos Aires: Hachette, 1983.

Apter, Emily. Against World Literature: On the Politics of Untranslatability. London: Verso, 2013.

Beecroft, Alexander. An Ecology of World Literature: From Antiquity to the Present Day. London: Verso, 2015.

Beecroft, Alexander. "World Literature Without a Hyphen." New Left Review 54 (2008), 87-100.

Cella, Susana, and Noé Jitrik, eds. Historia crítica de la literatura argentina: La irrupción de la crítica, vol. 10. Buenos Aires: Emecé Editores, 1999.

Coutinho, Eduardo F. "Comparative Studies in Latin America: The Role of Tania Franco Carvalhal." Comparative Critical Studies 7:2-3 (2010), 367-79.

Damrosch, David. "World Literature as Alternative Discourse." Neohelicon 38 (2011), 307-17.

Damrosch, David. What is World Literature? Princeton: Princeton UP, 2003.

Damrosch, David. "World literature in a Postcanonical, Hypercanonical Age." In Comparative Literature in an Age of Globalization. Ed. Haun Saussy. Baltimore: Johns Hopkins UP, 2004, 43-53.

David, Jerôme. Spectres de Goethe: Les métamorphoses de la “littérature mondiale." Paris: Les Prairies ordinaires, 2011.

Domínguez, César. “Literatura mundial en/desde el castellano." Ínsula 787-8 (July 2012), $2-6$.

Gerbaudo, Analía. "Los estudios literarios, su institucionalización en la universidad argentina y su internacionalización (1945-2010)." Lecture delivered at the Universitat de Barcelona, 28 Apr 2016.

Gilman, Claudia. Entre la pluma y el fusil: Debates y dilemas del escritor revolucionario en América Latina. Buenos Aires: Siglo Veintiuno, 2003.

Gramuglio, María Teresa. Nacionalismo y cosmopolitismo en la literatura argentina. Rosario: Editorial Municipal de Rosario, 2013.

Hidalgo Nácher, Max. "Los discursos de la crítica literaria argentina y la teoría literaria francesa (1953-1978)." $45^{\circ}{ }^{\circ} \mathrm{F}$ : Revista de Teoría de la Literatura y Literatura Comparada 12 (2015), 102-31.

Hoyos, Héctor. Beyond Bolaño: The Global Latin American Novel. New York: Columbia UP, 2015.

López, Magdalena, Ângela Fernandes, Isabel Araújo Branco, Margarida Borges, Raquel Baltazar, and Sonia Miceli. Act-29. Literaturas e culturas em Portugal e na Amé- 
rica Hispanica. Novas perspectivas em diálogo. V.N. Famalicão: Edições Húmus, 2014.

Moretti, Franco. “Conjectures on World Literature." New Left Review 1 (2000), 54-68.

Moretti, Franco. "More Conjectures on World Literature." New Left Review 20 (2003), 7381.

Moretti, Franco. Graphs, Maps, Trees: Abstract Models for a Literary History. London: Verso, 2005.

Müller, Gesine, and Dunia Gras Miravet, eds. América latina y la literatura mundial:mercado editorial, redes globales y la invención de un continente. Madrid and Frankfurt: Iberoamericana-Vervuert, 2015.

Pulido Tirado, Genara. "Del comparatismo espontáneo a la literatura mundial en América Latina." 1616: Anuario de Literatura Comparada 3 (2013), 273-99.

Said, Edward. The World, the Text, and the Critic. Cambridge, MA: Harvard UP, 1983.

Sánchez-Prado, Ignacio, ed. América latina en la "literatura mundial." Pittsburg: Instituto Internacional de Literatura Iberoamericana, Universidad de Pittsburg, 2006.

Sapiro, Gisèle. "How do Literary Works Cross Borders (or Not)? A Sociological Approach to World Literature." Journal of World Literature 1:1 (2016), 81-96.

Siskind, Mariano. Cosmopolitan Desires: Global Modernity and World Literature in Latin America. Evanston, IL: Northwestern UP, 2014. 